\title{
The Total Work of Breathing in Normal and Obese Men *
}

\author{
J. T. Sharp, J. P. Henry, S. K. Sweany, W. R. Meadows, and \\ R. J. Pietras \\ (From the Cardiopulmonary Laboratory of the Veterans Administration Hospital, Hines, Ill., \\ and the Departments of Medicine of the University of Illinois College of Medicine \\ and the Stritch School of Medicine of Loyola University, \\ Chicago, Ill.)
}

It has been long suspected that the increased work required to move the ponderous thoracic wall and abdomen during breathing was responsible for hypoventilation and retention of carbon dioxide in the obesity-hypoventilation or "Pickwickian" syndrome (1-4). Increased oxygen cost of ventilation, decreased lung compliance, increased pressure-volume work done on the lung, and increased intra-abdominal pressure have been reported in the extremely obese (5-8), and compliances of the thorax and the total respiratory system have been reported as low as one-fifth of normal in Naimark and Cherniack's obese subjects (9). Failure to find reports of the viscous resistance of the chest wall, which one might anticipate would be increased, and the total mechanical work of breathing in the extremely obese prompted us to make the measurements to be reported.

Alterations in the static volume-pressure curves of the thorax and total respiratory system found in severe obesity and produced by experimental mass-loading are dealt with elsewhere (10) as are changes in total respiratory inertance (11). The present paper deals principally with total respiratory work, and because the validity and accuracy of total respiratory work measurements depend upon the validity and precision of measurements of total respiratory compliance and total respiratory resistance, two methods of measuring each of these respiratory system properties have been employed and their results compared.

\section{Methods}

There were 22 subjects, eight of whom were normal adult males ranging from 29 to 45 years in age and from

\footnotetext{
* Submitted for publication August 27, 1963; accepted December 12, 1963.

Supported in part by National Institutes of Health grant H5124.
}

136 to $208 \mathrm{lbs}$. in weight. Of the 14 obese subjects, who ranged from 253 to $370 \mathrm{lbs}$. and 29 to 60 years, four had the obesity-hypoventilation syndrome. Two of the remaining ten obese subjects, to be referred to as the "obese normal" group, had mild arterial hypoxemia without hypercapnia. Table I gives conventional pulmonary function data on all subjects; Table II presents their respiratory mechanics.

In the four patients with the obesity-hypoventilation syndrome, the diagnosis was based upon the following criteria: 1) repeated demonstration of $\mathrm{PCO}_{2}$ levels in arterial blood above $48 \mathrm{~mm} \mathrm{Hg}$; 2) absence of definite clinical or physiologic evidence of other respiratory disorders commonly associated with carbon dioxide retention; 3 ) improvement or disappearance of arterial hypercapnia with reduction in weight.

Patients 2 and 3 were in right heart failure shortly before being studied but were edema-free with normal venous pressures when studied. Neither had evidence of left heart failure or pulmonary congestion.

Spirometry was done as described by Kory, Callahan, Boren, and Syner (12). The functional residual capacity was determined by the nitrogen washout method (13) using a rapidly responding nitrogen analyzer. The nitrogen washout curve was recorded on a direct writing oscillograph. The index of intrapulmonary mixing (13), the alveolar nitrogen percentage during a forced expiration at the termination of 7 minutes of the nitrogen washout, was read from the oscillographic record.

The single-breath carbon monoxide diffusing capacity was done as described by Ogilvie, Forster, Blakemore, and Morton (14). The oxygen saturation of arterial blood was measured by a spectrophotometric method (15). The arterial $\mathrm{pH}$ and $\mathrm{PCO}_{2}$ were measured at $37^{\circ} \mathrm{C}$ using a radiometer $\mathrm{pH}$ meter and the Astrup plasma equilibration method (16). All borderline and abnormal values were checked by determining the total blood carbon dioxide content (Van Slyke) and using the nomogram of Singer and Hastings (17). Values given by the two $\mathrm{PCO}_{2}$ methods checked within $2 \mathrm{~mm} \mathrm{Hg} . \quad \mathrm{PCO}_{2}$ values in excess of $48 \mathrm{~mm} \mathrm{Hg}$ are elevated for this laboratory.

Total respiratory system mechanics were determined by the tank respirator method described by Otis, Fenn, and Rahn(18). The validity of the method depends upon the subject's ability to relax his respiratory muscles and allow the tank respirator to perform his respiratory work. Figure 1 diagrams the apparatus employed. Tidal 
volume and air flow, measured in a "wedge" spirometer," and tank respirator pressure were recorded on a multichannel oscillograph (Figure 2). Data were recorded at three respirator cycling rates, 12,20 , and 30 breaths per minute, and at varying negative pressures up to minus $70 \mathrm{~cm} \mathrm{H}_{2} \mathrm{O}$. Respirator cycle amplitudes from ambient pressure to minus $25 \mathrm{~cm} \mathrm{H}_{2} \mathrm{O}$ were used, and periodically higher negative pressures were applied with a vacuum cleaner powered through a variable transformer.

Static volume-pressure curves for the total respiratory system were constructed by plotting the volume at "static" points of zero air flow against the simultaneously recorded tank respirator pressure (Figures 2 and 3 ).

${ }^{1}$ Custom Engineering and Development Co., St. Louis, Mo.
Total respiratory compliance was calculated as the mean slope $(\Delta \mathrm{V} / \Delta \mathrm{P})$ of the static volume-pressure curve from the resting mid-position to $1.5 \mathrm{~L}$ above it. $1.5 \mathrm{~L}$ was chosen because in all subjects the mid-portion of the curve was linear at least to this point. Total respiratory resistance was calculated at air flows of 0.5 $\mathrm{L}$ per second from tank respirator data by applying the resistance calculation of von Neergaard and Wirz (19), the tank respirator pressure being treated as is esophageal pressure in the pulmonary resistance calculation. Breaths of modest amplitude associated with respirator pressures less than minus $30 \mathrm{~cm} \mathrm{H}_{2} \mathrm{O}$ were used for resistance measurements and only consistently reproducible cycles measured. Resistance values were based on four to eight resistance measurements on each of five

TABLE I

Lung volume and gas exchange data on eight normal and fourteen excessively obese subjects*

\begin{tabular}{|c|c|c|c|c|c|c|c|c|c|c|c|c|c|c|}
\hline $\begin{array}{c}\text { Subject } \\
\text { no. }\end{array}$ & Age & Height & Wt. & M.B.C. & $\begin{array}{l}1 \text {-sec- } \\
\text { ond } \\
\text { timed } \\
\text { V.C. }\end{array}$ & V.C. & F.R.C. & R.V. & E.R.V. & T.L.C. & $\begin{array}{c}\text { Pul- } \\
\text { mo- } \\
\text { nary } \\
\text { mixing } \\
\text { index }\end{array}$ & Dlco & $\mathrm{SaO} 2$ & $\mathrm{PaCO} 2$ \\
\hline & yrs & inches & lbs & $L / \min$ & $\begin{array}{c}\% \\
\text { total }\end{array}$ & $L$ & $L$ & $L$ & $L$ & $L$ & $\begin{array}{l}\% \\
N_{2}\end{array}$ & $\underset{m i n}{m l /}$ & $\%$ & $m m H g$ \\
\hline \multicolumn{15}{|c|}{ Normal subjects } \\
\hline 1 & 35 & 71 & 180 & & 79 & 5.86 & 2.87 & 1.11 & 1.76 & 6.97 & 1.1 & 30.1 & & \\
\hline 2 & 45 & 73 & 171 & 178 & 77 & 6.46 & 3.64 & 0.92 & 2.72 & 6.76 & 0.6 & 29.6 & & \\
\hline 3 & 34 & 66 & 171 & 160 & 83 & 4.50 & 3.22 & 1.76 & 1.46 & 8.26 & 0.4 & 38.3 & & \\
\hline 4 & 40 & 68 & 152 & 145 & 78 & 4.85 & 2.75 & 1.09 & 1.67 & 5.94 & 1.0 & 27.8 & & \\
\hline 5 & 29 & 73 & 206 & 146 & 84 & 4.94 & 2.30 & 0.70 & 1.60 & 5.64 & 0.3 & 31.3 & & \\
\hline 6 & 30 & 66 & 136 & 154 & 88 & 4.30 & 3.11 & 0.95 & 2.13 & 5.25 & & 21.6 & & \\
\hline 7 & 39 & 70 & 175 & 146 & 87 & 4.45 & 3.11 & 1.96 & 1.22 & 6.40 & 0.7 & 31.8 & & \\
\hline 8 & 35 & 70 & 208 & 150 & 87 & 4.45 & 1.89 & 0.70 & 1.19 & 5.15 & 0.3 & 29.4 & & \\
\hline Mean & 35.8 & 69.6 & 175 & 156 & 83 & 4.28 & 2.86 & 1.15 & 1.72 & 6.05 & 0.6 & 30.0 & & \\
\hline \multicolumn{15}{|c|}{ Obese normal subjects } \\
\hline 1 & 44 & 68 & 304 & 120 & 79 & 4.37 & 2.15 & 1.53 & 0.62 & 5.90 & 1.1 & 29.5 & 92 & 33 \\
\hline 2 & 40 & 72 & 328 & 106 & 82 & 3.76 & 1.92 & 0.96 & 0.95 & 4.73 & 1.0 & 25.0 & 97 & 33 \\
\hline 3 & 29 & 70 & 331 & 109 & 76 & 3.76 & 2.96 & 2.32 & 0.65 & 6.08 & 0.7 & 26.9 & 94 & 34 \\
\hline 4 & 41 & 68 & 295 & 152 & 83 & 3.96 & 1.48 & 0.86 & 0.61 & 4.84 & 1.0 & & 95 & 43 \\
\hline 5 & 38 & 71 & 260 & 103 & 73 & 3.76 & 2.38 & 1.53 & 0.85 & 5.28 & 1.1 & 32.0 & 96 & 44 \\
\hline 6 & 40 & 68 & 282 & 128 & 84 & 3.28 & 1.50 & 1.07 & 0.43 & 4.27 & 0.6 & 28.6 & 96 & 34 \\
\hline 7 & 51 & 68 & 260 & 112 & 79 & 3.98 & 3.05 & 2.39 & 0.66 & 6.38 & 1.3 & 23.3 & 95 & 40 \\
\hline 8 & 35 & 75 & 325 & 129 & 78 & 3.88 & 1.83 & 1.29 & 0.53 & 5.17 & 0.4 & 22.3 & 97 & 41 \\
\hline 9 & 43 & 70 & 308 & 118 & 75 & 4.78 & 3.07 & 2.13 & 0.94 & 6.91 & 2.6 & 31.0 & 91 & 46 \\
\hline 10 & 41 & 69 & 350 & 99 & 74 & 4.86 & 2.64 & 1.39 & 1.25 & 6.25 & 2.9 & 35.7 & 98 & 38 \\
\hline Mean & 40.2 & 69.9 & 304 & 118 & 78 & 4.03 & 2.20 & 1.55 & 0.75 & 5.58 & 1.3 & 28.3 & 95 & 39 \\
\hline \multicolumn{15}{|c|}{ Obesity hypoventilation syndrome } \\
\hline 1 & 43 & 74 & 367 & 120 & 83 & 3.39 & 2.11 & 1.17 & 0.94 & 4.56 & 1.3 & 24.5 & 92 & 52 \\
\hline $1 \mathrm{a}$ & & & 350 & 96 & 87 & 3.26 & 2.10 & 1.13 & 0.98 & 4.39 & 1.6 & & 94 & 45 \\
\hline 2 & 60 & 64 & 253 & 57 & 86 & 2.24 & 1.91 & 1.37 & 0.54 & 3.83 & 1.8 & 19.5 & 88 & 52 \\
\hline $2 a$ & & & 207 & 65 & 84 & 2.58 & 2.35 & 1.51 & 0.84 & 4.09 & 0.9 & & 96 & 44 \\
\hline 3 & 46 & 68 & 370 & 81 & 64 & 2.80 & 1.69 & 1.34 & 0.35 & 4.11 & 2.1 & 30.8 & 76 & 62 \\
\hline $3 a$ & & & 320 & 92 & 80 & 2.78 & 2.40 & 1.54 & 0.85 & 3.96 & 4.7 & & 88 & 52 \\
\hline 4 & 38 & 66 & 289 & 96 & 89 & 2.72 & 1.13 & 0.95 & 0.19 & 3.67 & 3.7 & 21.4 & $\left\{\begin{array}{l}91 \mathrm{w} \\
80 \mathrm{~s}\end{array}\right.$ & $\begin{array}{l}42 w \\
60 s\end{array}$ \\
\hline Mean, study 1 & 46.7 & 68 & 320 & 89 & 81 & 2.79 & 1.71 & 1.21 & 0.51 & 4.04 & 2.2 & 24.1 & 87 & 57 \\
\hline Mean, study 2 & & & 292 & 84 & 84 & 2.87 & 2.26 & 1.39 & 0.89 & 4.15 & 2.4 & & 93 & 47 \\
\hline
\end{tabular}

* M.B.C. is maximal breathing capacity in liters per minute, body temperature, pressure, saturated with water (BTPS); V.C., F.R.C., R.V., E.R.V., and T.L.C. are, respectively, vital capacity, functional residual capacity, residual volume, expiratory reserve volume, and total lung capacity in liters, BTPS. The pulmonary mixing index is the alveolar nitrogen percentage after 7 minutes of $100 \%$ oxygen breathing and is normally less than $2.5 \%$. The DLCo is the single-breath carbon monoxide diffusing capacity in milliliters CO per millimeter Hg per minute. SaO2 and Paco are, respectively, the arterial oxygen saturation in percentage and the arterial carbon dioxide tension in millimeters Hg. Two studies were done on, after the subject number. Means of the first and second studies are indicated. The letters $w$ and s after the PacO2 and SaOz in O.H. Patient 4 refer to waking $(\mathrm{w})$ and sleeping ( $\mathrm{s}$ ) obervations. 
TABLE II

Lung, thoracic, and total respiratory mechanics on all subjects*

\begin{tabular}{|c|c|c|c|c|c|c|c|c|c|c|c|c|}
\hline \multirow{4}{*}{$\begin{array}{l}\text { Subject } \\
\text { no. }\end{array}$} & \multicolumn{4}{|c|}{ Compliances } & \multicolumn{5}{|c|}{ Inspiratory resistances } & & & \\
\hline & \multirow[b]{3}{*}{ Lung } & \multirow[b]{3}{*}{ Thorax } & \multirow{3}{*}{$\begin{array}{l}\text { Total } \\
\text { tank } \\
\text { respira- } \\
\text { tor }\end{array}$} & \multirow{3}{*}{$\begin{array}{c}\text { Total } \\
\text { mid- } \\
\text { position } \\
\text { shift }\end{array}$} & \multicolumn{3}{|c|}{ Thorax } & \multicolumn{2}{|c|}{ Total } & \multirow{2}{*}{\multicolumn{3}{|c|}{ Respiratory work }} \\
\hline & & & & & & $\begin{array}{l}\text { Tank } \\
\text { respira- }\end{array}$ & & $\begin{array}{l}\text { Tank } \\
\text { respira. }\end{array}$ & & & & \\
\hline & & & & & Lung & & Oscill. & & Oscill. & Lung & Thorax & Total \\
\hline & \multicolumn{4}{|c|}{$\mathrm{L} / \mathrm{cm} \mathrm{H}_{2} \mathrm{O}$} & \multicolumn{5}{|c|}{$\begin{array}{l}\text { cm } \mathrm{H}_{2} \mathrm{O} / \mathrm{L} / \mathrm{sec} \\
\text { jects }\end{array}$} & \multicolumn{3}{|c|}{$\mathrm{kg}-\mathrm{m} / 1 \mathrm{~L}$ breath at $20 \mathrm{BPM}$} \\
\hline $\begin{array}{l}1 \\
2 \\
3 \\
4 \\
5 \\
6 \\
7 \\
8\end{array}$ & $\begin{array}{l}0.200 \\
0.310 \\
0.253 \\
0.159 \\
0.240 \\
0.214 \\
0.186 \\
0.128\end{array}$ & $\begin{array}{l}0.250 \\
0.230 \\
0.183 \\
0.208 \\
0.140 \\
0.202 \\
0.231 \\
0.270\end{array}$ & $\begin{array}{l}0.111 \\
0.131 \\
0.106 \\
0.090 \\
0.095 \\
0.106 \\
0.103 \\
0.087\end{array}$ & $\begin{array}{l}0.131 \\
0.156 \\
0.101 \\
0.080 \\
0.091 \\
0.101 \\
0.117 \\
0.088\end{array}$ & $\begin{array}{l}1.7 \\
1.6 \\
2.1 \\
1.0 \\
1.3 \\
0.7 \\
1.2 \\
1.1\end{array}$ & $\begin{array}{l}2.3 \\
3.8 \\
1.0 \\
3.7 \\
1.4 \\
6.0 \\
4.5 \\
4.7\end{array}$ & $\begin{array}{l}0.2 \\
0.2 \\
0.0 \\
1.2 \\
0.5 \\
1.0 \\
0.6 \\
0.5\end{array}$ & $\begin{array}{l}4.0 \\
5.4 \\
3.1 \\
4.7 \\
2.7 \\
6.7 \\
5.7 \\
5.8\end{array}$ & $\begin{array}{l}1.9 \\
1.8 \\
2.1 \\
2.2 \\
1.8 \\
1.7 \\
1.8 \\
1.6\end{array}$ & $\begin{array}{l}0.028 \\
0.022 \\
0.039 \\
0.047 \\
0.032 \\
0.034 \\
0.029 \\
0.048\end{array}$ & $\begin{array}{l}0.024 \\
0.045 \\
0.056 \\
0.031 \\
0.028 \\
0.036 \\
0.052 \\
0.034\end{array}$ & $\begin{array}{l}0.052 \\
0.067 \\
0.095 \\
0.078 \\
0.060 \\
0.070 \\
0.081 \\
0.082\end{array}$ \\
\hline $\begin{array}{l}\text { Mean } \\
\text { SE }\end{array}$ & $\begin{array}{l}0.211 \\
0.020\end{array}$ & $\begin{array}{l}0.214 \\
0.014\end{array}$ & $\begin{array}{l}0.104 \\
0.005\end{array}$ & $\begin{array}{l}0.108 \\
0.004\end{array}$ & $\begin{array}{l}1.3 \\
0.1\end{array}$ & $\begin{array}{l}3.4 \\
0.6\end{array}$ & $\begin{array}{l}0.5 \\
0.01\end{array}$ & $\begin{array}{l}4.8 \\
0.5\end{array}$ & $\begin{array}{l}1.9 \\
0.07\end{array}$ & $\begin{array}{l}0.035 \\
0.003\end{array}$ & $\begin{array}{l}0.038 \\
0.004\end{array}$ & $\begin{array}{l}0.073 \\
0.005\end{array}$ \\
\hline \multicolumn{13}{|c|}{ Obese normal subjects } \\
\hline $\begin{array}{l}1 \\
2 \\
3 \\
4 \\
5 \\
6 \\
7 \\
8\end{array}$ & $\begin{array}{l}0.154 \\
0.109 \\
0.107 \\
0.165 \\
0.113 \\
0.085 \\
0.184\end{array}$ & $\begin{array}{l}0.222 \\
0.145 \\
0.141 \\
0.217 \\
0.274 \\
0.192 \\
0.163\end{array}$ & $\begin{array}{l}0.091 \\
0.062 \\
0.061 \\
0.089 \\
0.080 \\
0.059 \\
0.086 \\
0.063\end{array}$ & $\begin{array}{l}0.095 \\
0.033 \\
0.050 \\
0.080 \\
0.086 \\
0.063 \\
0.116 \\
0.056\end{array}$ & $\begin{array}{l}4.1 \\
2.9 \\
5.0 \\
2.6 \\
4.8 \\
3.1 \\
3.9\end{array}$ & $\begin{array}{l}3.8 \\
4.8 \\
1.5 \\
3.8 \\
4.0 \\
6.7 \\
4.2\end{array}$ & $\begin{array}{l}\text { neg } \\
0.9 \\
\text { neg } \\
0.0 \\
0.4 \\
0.1 \\
\text { neg }\end{array}$ & $\begin{array}{l}7.9 \\
7.7 \\
6.5 \\
6.4 \\
8.8 \\
9.9 \\
8.1\end{array}$ & $\begin{array}{l}2.3 \\
3.8 \\
2.2 \\
2.6 \\
5.2 \\
3.2 \\
3.0 \\
2.4\end{array}$ & $\begin{array}{l}0.036 \\
0.047 \\
0.067 \\
0.048 \\
0.075 \\
0.076 \\
0.056\end{array}$ & $\begin{array}{l}0.033 \\
0.024 \\
0.081 \\
0.048 \\
0.051 \\
0.024 \\
0.042\end{array}$ & $\begin{array}{l}0.069 \\
0.071 \\
0.148 \\
0.096 \\
0.126 \\
0.100 \\
0.098\end{array}$ \\
\hline $\begin{array}{r}9 \\
10\end{array}$ & $\begin{array}{l}0.250 \\
0.250\end{array}$ & $\begin{array}{l}0.141 \\
0.270\end{array}$ & $\begin{array}{l}0.090 \\
0.130\end{array}$ & & $\begin{array}{l}2.9 \\
4.3\end{array}$ & $\begin{array}{r}7.7 \\
\text { neg }\end{array}$ & & $\begin{array}{r}10.6 \\
3.1\end{array}$ & & $\begin{array}{l}0.049 \\
0.083\end{array}$ & $\begin{array}{l}0.042 \\
\text { neg }\end{array}$ & $\begin{array}{l}0.091 \\
0.055\end{array}$ \\
\hline $\begin{array}{l}\text { Mean } \\
\text { SE }\end{array}$ & $\begin{array}{l}0.157 \\
0.020\end{array}$ & $\begin{array}{l}0.196 \\
0.018\end{array}$ & $\begin{array}{l}0.081 \\
0.007\end{array}$ & $\begin{array}{l}0.072 \\
0.010\end{array}$ & $\begin{array}{l}3.8 \\
0.3\end{array}$ & $\begin{array}{l}4.6 \\
0.7\end{array}$ & & $\begin{array}{l}7.7 \\
0.7\end{array}$ & $\begin{array}{l}3.1 \\
0.12\end{array}$ & $\begin{array}{l}0.054 \\
0.006\end{array}$ & $\begin{array}{l}0.043 \\
0.006\end{array}$ & $\begin{array}{l}0.095 \\
0.010\end{array}$ \\
\hline \multicolumn{13}{|c|}{ Obesity hypoventilation syndrome } \\
\hline $\begin{array}{l}1 \\
1 \mathrm{a} \\
2 \\
2 \mathrm{a} \\
3 \\
3 \mathrm{a} \\
4\end{array}$ & $\begin{array}{l}0.142 \\
0.097 \\
0.141 \\
0.109\end{array}$ & $\begin{array}{l}0.072 \\
0.052 \\
0.108 \\
0.095 \\
0.060 \\
0.080 \\
0.073\end{array}$ & $\begin{array}{l}0.048 \\
0.038 \\
0.051 \\
0.048 \\
0.042 \\
0.051 \\
0.044\end{array}$ & $\begin{array}{l}0.038 \\
0.052 \\
0.051 \\
0.031\end{array}$ & $\begin{array}{l}2.5 \\
4.6 \\
5.0 \\
3.2\end{array}$ & $\begin{array}{r}13.7 \\
7.5 \\
4.8 \\
5.0\end{array}$ & 1.0 & $\begin{array}{r}16.2 \\
5.1 \\
12.1 \\
14.0 \\
9.8 \\
7.1 \\
8.2\end{array}$ & $\begin{array}{l}3.3 \\
3.2 \\
2.7 \\
4.2\end{array}$ & $\begin{array}{l}0.066 \\
0.107 \\
0.097 \\
0.068\end{array}$ & $\begin{array}{l}0.128 \\
0.138 \\
0.067 \\
0.175\end{array}$ & $\begin{array}{l}0.194 \\
0.140 \\
0.245 \\
0.174 \\
0.164 \\
0.128 \\
0.243\end{array}$ \\
\hline $\begin{array}{l}\text { Mean, study } 1 \\
\text { SE }\end{array}$ & $\begin{array}{l}0.122 \\
0.036\end{array}$ & $\begin{array}{l}0.079 \\
0.010\end{array}$ & $\begin{array}{l}0.046 \\
0.002\end{array}$ & & $\begin{array}{l}3.8 \\
0.6\end{array}$ & $\begin{array}{l}7.8 \\
2.1\end{array}$ & & $\begin{array}{r}11.6 \\
1.8\end{array}$ & & $\begin{array}{l}0.085 \\
0.010\end{array}$ & $\begin{array}{l}0.127 \\
0.022\end{array}$ & $\begin{array}{l}0.212 \\
0.021\end{array}$ \\
\hline $\begin{array}{l}\text { Mean, study } 2 \\
\text { SE }\end{array}$ & & $\begin{array}{l}0.075 \\
0.009\end{array}$ & $\begin{array}{l}0.045 \\
0.003\end{array}$ & $\begin{array}{l}0.043 \\
0.005\end{array}$ & & & & $\begin{array}{l}8.6 \\
1.9\end{array}$ & $\begin{array}{l}3.4 \\
0.3\end{array}$ & & & $\begin{array}{l}0.147 \\
0.014\end{array}$ \\
\hline
\end{tabular}

* Oscill. refers to measurements of resistance made by the oscillatory method. Mid-position shift refers to measurements of total compliance made by the mid-position shift method of Heaf and Prime. All gas volumes are expressed in liters, BTPS. BPM = breaths per minute.

breaths. Total inspiratory work was calculated by measuring the area of volume-pressure plots of tank respirator pressure against inspired volume. It was expressed as kilogram-meters of volume-pressure work required to inspire a 1-L breath at 20 breaths per minute.

Pulmonary compliance and resistance and the work done on the lung were calculated by conventional methods from recordings of esophageal presure, air flow, and tidal volume measured in the sitting position. The sitting position was used for lung mechanics because of an esophageal pressure artifact which often occurs in the supine position. The Mead-Whittenberger oscilloscopic subtraction method (20) was used for pulmonary resistance when it was compared with the pulmonary component of total resistance measured by the oscillatory method. Static volume-pressure curves for the lung were measured by using an interrupter as previously described (21). Thoracic ${ }^{2}$ resistance was obtained by

2 The term "thoracic" is used here in the broad sense as applying to all structures surrounding the lung which are moved during respiration. It therefore includes the rib cage, diaphragm, and abdominal contents. 


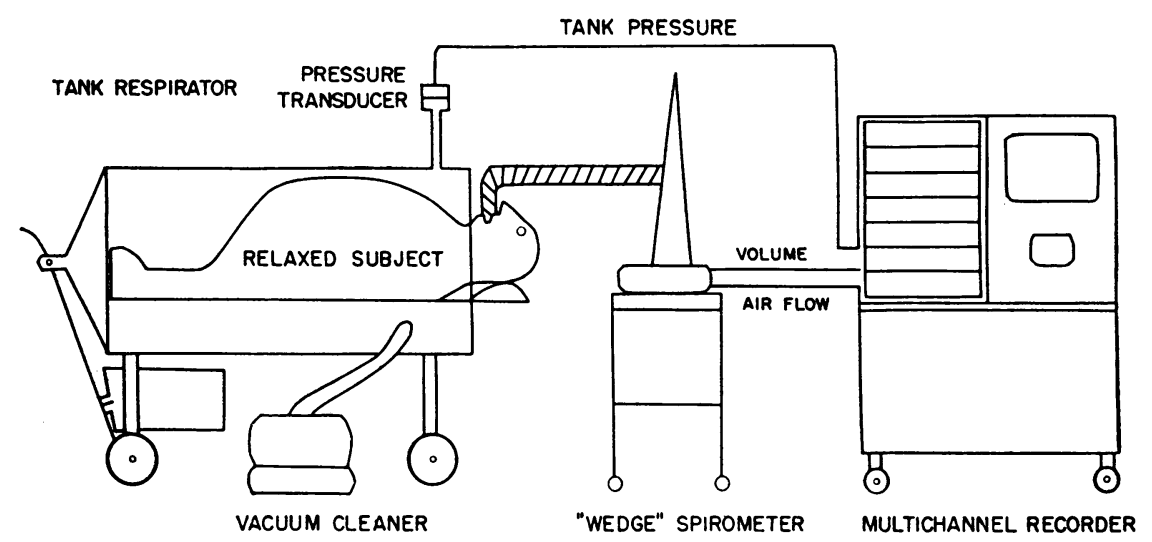

Fig. 1. Apparatus used to Measure total Respiratory mechanics.

subtracting pulmonary resistance from the total respiratory system resistance. Thoracic compliance was calculated from the relationship between capacitive elements in series: $1 / C_{T}=1 / C_{L}+1 / C_{W}$, where $C_{T}=$ total respiratory compliance, $C_{W}=$ thoracic wall compliance, and $C_{L}=$ lung compliance.

Uncertainty about complete subject relaxation led to the use of independent methods for measuring both total compliance and total resistance. Naimark and Cherniack's modification (9) of the mid-position shift method of Heaf and Prime (22) was used for measuring total compliance. As shown in Figure 4, steady negative pressures were applied to the supine subject enclosed in a tank respirator, and the resulting shift in respiratory midposition was recorded. When several ( 8 to 20 ) different negative pressures were applied to the thorax, the static volume-pressure curve of the total respiratory system could be obtained. The validity of this method depends

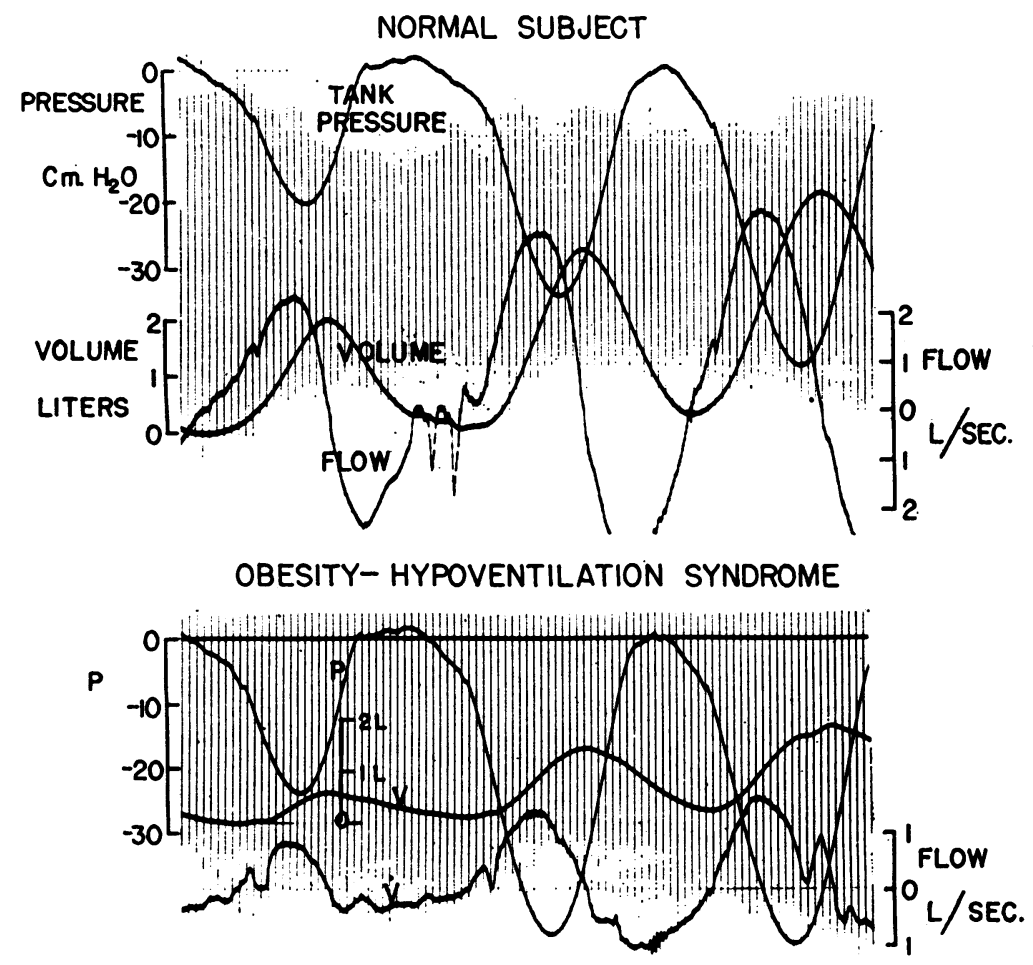

Fig. 2. Tracings of tank Respirator pressure, tidal volume, and air FLOW IN A NORMAL SUBJECT AND IN A PATIENT WITH THE OBESITY-HYPOventilation (O.H.) SYNDROME. Respirator pressure cycles of comparable amplitude give a much greater tidal volume in the normal subject than in the O.H. patient. Time lines are at 0.1 -second intervals. 


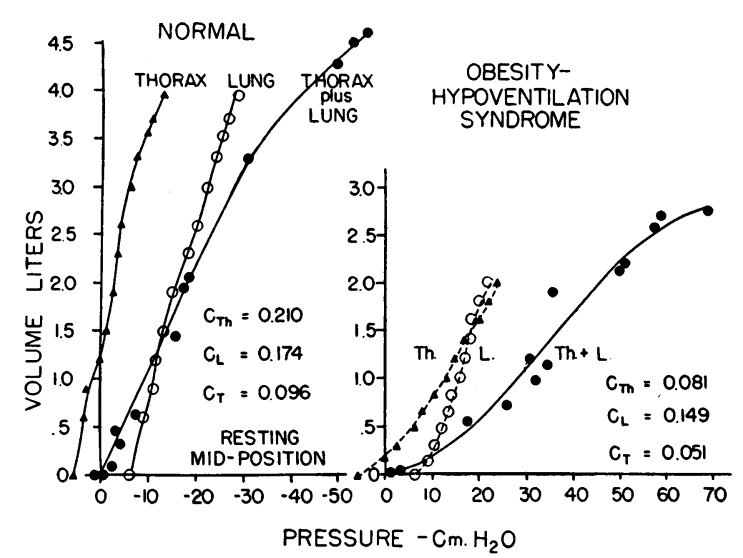

Fig. 3. Static volume-PRessure curves of thorax, LUNG, AND TOTAL RESPIRATORY SYSTEM IN A NORMAL SUBJECT AND IN A PATIENT WITH THE OBESITY-HYPOVENTILATION SYNDROME. See text for discussion.

upon the observation made by Naimark and Cherniack (9) that no action potentials are detectable over respiratory muscles at the resting mid-position even during application of external pressure.

The independent total respiratory resistance method used was Mead's modification (23) of the oscillatory method of Dubois, Brody, Lewis, and Burgess (24). Sine waves of pressure were applied to a subject's body surface at the natural frequency of the respiratory system at which its mechanical reactance was zero. Because at this frequency the effects of compliance and inertance exactly neutralized one another, the mechanical impedance of the respiratory system was wholly resistive, and the quotient $\Delta$ applied pressure $/ \Delta$ air flow equaled the total respiratory system resistance. This was determined as the slope of the oscilloscopic " $x-y$ " plot of applied pressure against air flow. Total resistance values ob- tained by this method represented minimal resistance, because the steepest slopes observed consistently were used for resistance calculations. They were measured near the subject's resting mid-position at air flows of 0.5 $\mathrm{L}$ per second and represent principally the laminar flow or linear component of airway resistance plus lung and thoracic tissue resistances. These measurements apply to quiet breathing, where air flows do not usually exceed 0.7 or $0.8 \mathrm{~L}$ per second, and air flow is mostly laminar. Total resistance values are averages derived from between three and seven oscilloscopic photographs.

Action potentials of upper anterolateral intercostals (2nd, 3rd, and 4th), rectus abdominus, and external oblique muscles were sensed through bipolar silver skin electrodes, $0.5 \mathrm{~cm}$ in diameter, with a commercial electromyograph machine. ${ }^{3}$

\section{Results}

Compliances and static volume-pressure curves. Figure 3 shows static volume-pressure curves for the total respiratory system, the thorax, and the lungs. Differences in slope and shape of the total respiratory and thoracic curves between the normal subject and the patient with the obesity-hypoventilation (O.H.) syndrome are obvious. Flatter slopes in many of the total respiratory volumepressure curves at small volumes reflect the similar shapes of the thoracic curves, as lung volumepressure curves were essentially linear. This curved configuration was present in six of the obese normal subjects and in all O.H. patients and was associated with reduction of the func-

${ }^{3}$ Disa Electronics, Copenhagen, Denmark.

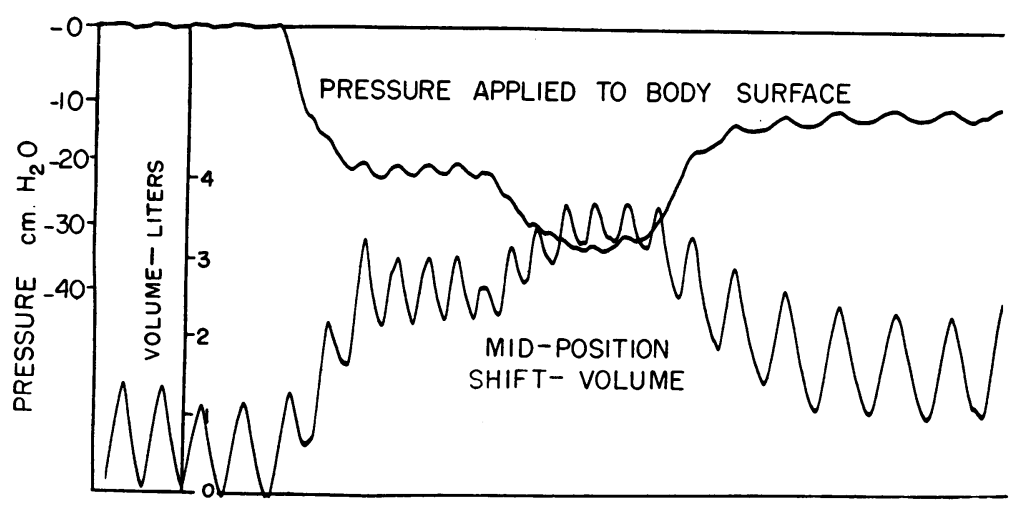

Fig. 4. Modification of the Mid-position Shift method of Heaf and PRIME FOR MEASURING TOTAL ReSPIRATORY COMPLIANCE. A steady negative pressure (upper tracing) is applied to the surface of the body enclosed in a tank respirator or plethysmograph, and the resulting volume shift in the resting mid-position is recorded (bottom tracing). Three different pressures were applied in the tracing, and three volume shifts resulted. 


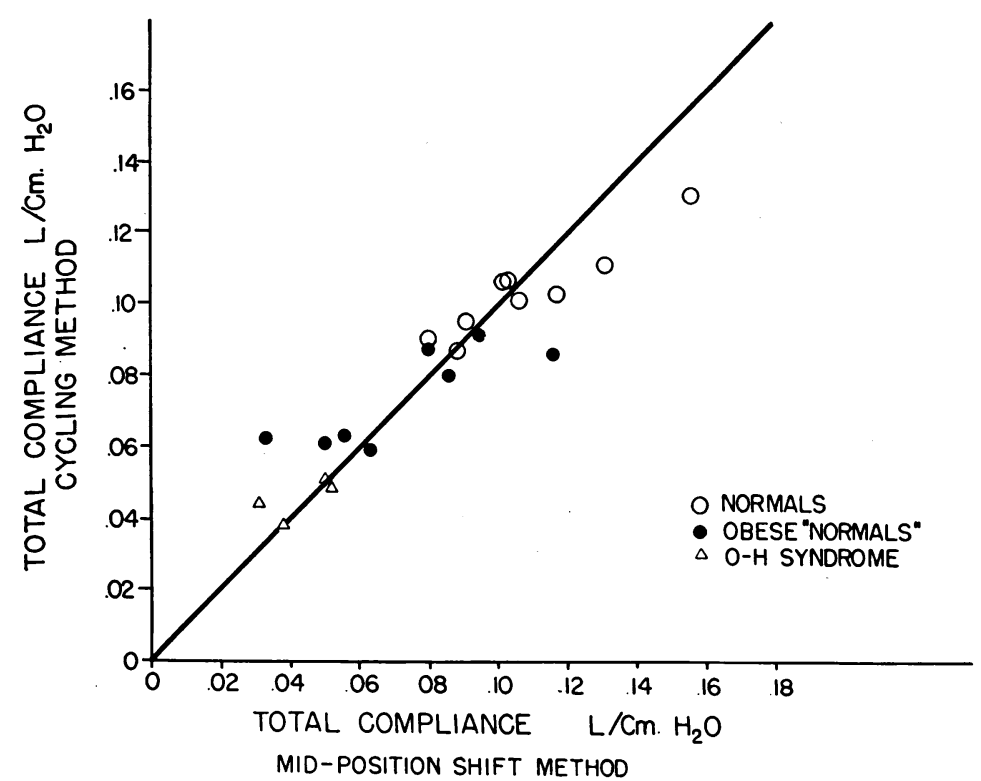

Fig. 5. Graphic comparison of the tank RESPirator (ORDINATE) AND MID-POSITION SHIFT (ABSCISSA) TOTAL COMPLIANCE METHODS. The diagonal line is the line of identity. The correlation coefficient is +0.93 . +0.93 .

tional residual capacity below the predicted normal owing to the thoracic and abdominal compressive effect of obesity. Changes in the shape of the volume-pressure curve are dealt with elsewhere (10).
Lung, thoracic, and total compliances for all subjects are given in Table II. The two total respiratory compliance methods gave similar values (Figure 5), and the correlation coefficient between their results was +0.93 . With the tank

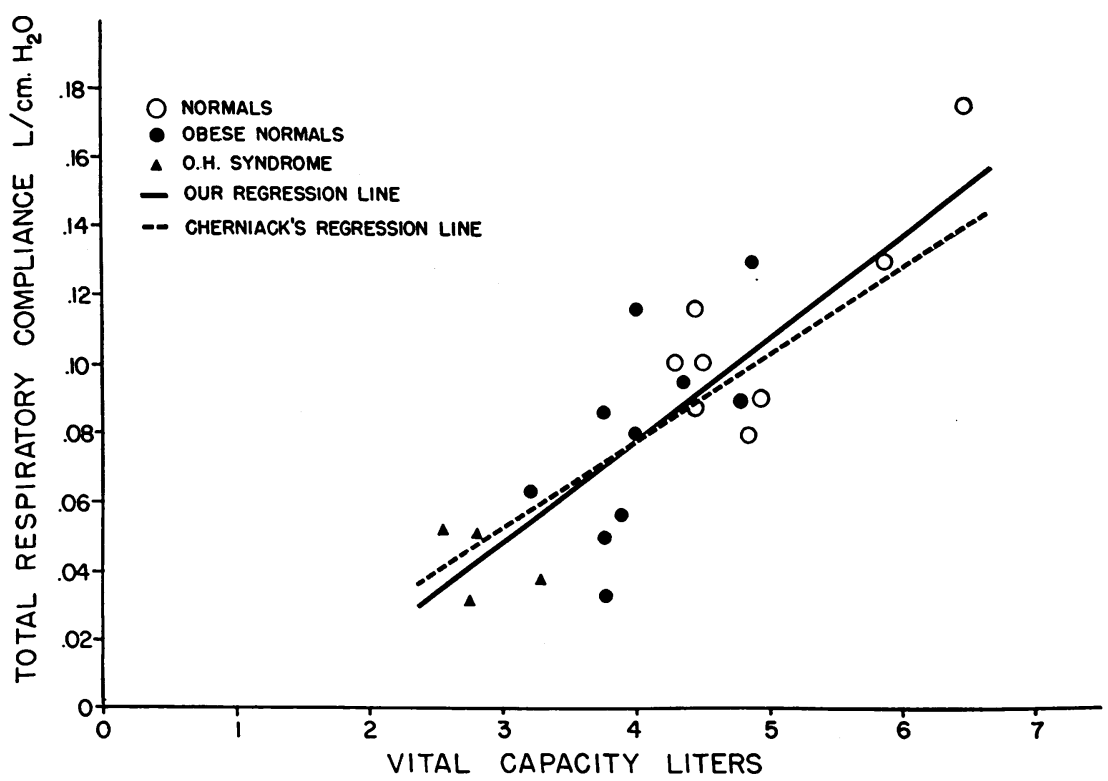

Fig. 6. RELATIONSHIP BETWEEN TOTAL RESPIRATORY COMPLIANCE AND THE VITAL CAPACITY. The correlation coefficient is t0.84. The solid regression line is derived from our data; for comparison we have shown a regression line (broken line) derived from the supine data of Naimark and Cherniack. 
respirator method group averages in liters per centimeters $\mathrm{H}_{2} \mathrm{O}( \pm \mathrm{SE})$ were $0.104 \pm 0.005$, $0.081 \pm 0.007$, and $0.045 \pm 0.003$ respectively for normal subjects, obese normal subjects, and O.H. syndrome patients. The mid-position shift method gave average values of $0.109 \pm 0.009,0.072 \pm$ 0.010 , and $0.043 \pm 0.005$ for the three groups. By both methods significant differences ( $p$ $<0.05$ ) were present among the subject groups. In three of the four patients with the hypoventilation syndrome, follow-up studies done after weight loss associated with decrease in $\mathrm{PCO}_{2}$ revealed no significant changes in total respiratory compliance despite clinical and physiologic improvement.

Total respiratory compliance was related to the vital capacity (Figure 6) with a correlation coefficient of $+0.84(\mathrm{p}<.001)$. This relationship was close to that observed by Naimark and Cherniack (9) in their supine studies.

Lung compliance (in liters per centimeter $\mathrm{H}_{2} \mathrm{O}$ $\pm \mathrm{SE}$ ) averaged $0.211 \pm 0.020$ in the normal subjects, $0.157 \pm 0.020$ in the obese normal subjects, and $0.122 \pm 0.036$ in the O.H. patients. Group differences were not significant at the 0.05 level.

Thoracic compliance averaged $0.214 \pm 0.014$ in the normal subjects, $0.196 \pm 0.018$ in the obese normal subjects, and $0.075 \pm 0.009$ in the

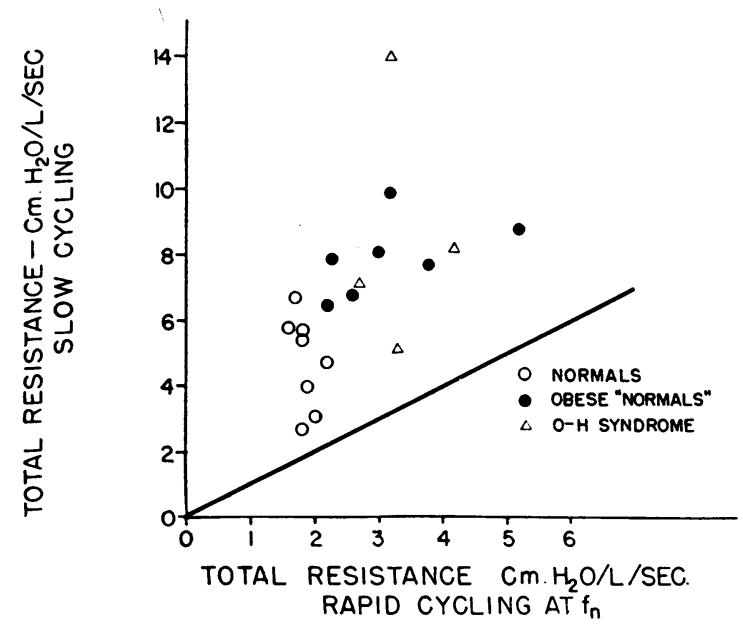

Fig. 7. COMPARISON OF THE TANK RESPIRATOR (ORDINATE) AND OSCILLATORY (ABSCISSA) METHODS FOR MEASURING TOTAL RESPIRATORY RESISTANCE. The diagonal line is the line of identity. Although the obese patients had higher resistances than normal subjects by both methods, the two methods do not appear to measure the same thing. patients with the O.H. syndrome. The differences between the normal subjects and the O.H. patients and between the obese normal subjects and O.H. patients were highly significant ( $\mathrm{p}$ $<0.001)$.

Resistances. By the tank respirator method total inspiratory resistance in the normal subjects averaged $4.8 \pm 0.5 \mathrm{~cm} \mathrm{H}_{2} \mathrm{O}$ per $\mathrm{L}$ per second. In the obese normal subjects it averaged $7.7 \pm 0.72$ and in the O.H. patients, $11.6 \pm 1.8 \mathrm{~cm} \mathrm{H}_{2} \mathrm{O}$ per $\mathrm{L}$ per second. The normal subjects were significantly different from the obese normal subjects and the O.H. patients $(p<0.01)$, but the obese normal subjects and O.H. patients did not differ significantly. The three O.H. patients who improved had an average total resistance of 8.6 \pm 1.91 when restudied.

The oscillatory total resistance method gave group mean values of $1.9 \pm 0.07$ (SE), 3.1 \pm 0.35 , and $3.4 \pm 0.31 \mathrm{~cm} \mathrm{H}_{2} \mathrm{O}$ per $\mathrm{L}$ per second, respectively, for normal, obese normal, and O.H. patients. Differences between normal and obese normal subjects and between normal subjects and O.H. patients were significant $(\mathrm{p}<0.01)$. Increases in total respiratory resistance as measured by this method in the obese subjects were due almost entirely to increases in pulmonary resistance.

Pulmonary resistance in the normal subjects averaged $1.3 \pm 0.1$ (SE); in the obese normal subjects, $3.8 \pm 0.3$; and in the O.H. patients, $3.8 \pm 0.6 \mathrm{~cm} \mathrm{H}_{2} \mathrm{O}$ per $\mathrm{L}$ per second. Differences between the normal subjects and both obese groups are significant $(\mathrm{p}<0.01)$.

Two values for thoracic resistance are given for each subject, one obtained by subtracting pulmonary resistance from total resistance measured by the tank respirator method and the other obtained by subtracting the same pulmonary resistance value from the total resistance measured by the oscillatory method. The tank respiratory method gave mean values of $3.4 \pm 0.06,4.6$ \pm 0.07 , and $7.8 \pm 2.1 \mathrm{~cm} \mathrm{H}_{2} \mathrm{O}$ per $\mathrm{L}$ per second for normal, obese normal, and O.H. patient groups, respectively. The oscillatory method gave a mean value of $0.51 \pm 0.014$ for the normal subjects. This is reasonably close to thoracic resistance values of 0.69 obtained in four normal subjects studied by Ferris, Mead, and Opie (25). 
In obese normal and O.H. groups several negative values for thoracic resistance were encountered. This may be related to the fact that measurements of pulmonary and total respiratory resistance were not simultaneous. Comparison of values given by the two total respiratory resistance methods indicate that the two methods are not measuring the same thing (Figure 7).

Certain data were obtained in an attempt to explain the difference between oscillatory and tank respirator resistances. They will be presented here and discussed below. Because respirator resistances were measured supine and oscillatory resistances sitting, a comparison of the pulmonary component of total resistance was made in O.H. Patients 1 and 2, in the sitting versus the supine positions. Changing from the sitting to the supine position increased pulmonary resistance by 1.2 and $1.4 \mathrm{~cm} \mathrm{H}_{2} \mathrm{O}$ per $\mathrm{L}$ per second, respectively, in Patients 1 and 2. Exploring the same question, oscillatory total resistances were measured in both sitting and supine positions in five normal subjects, and a mean resistance increase of $0.3 \mathrm{~cm} \mathrm{H}_{2} \mathrm{O}$ per $\mathrm{L}$ per second occurred on becoming supine. This could be wholly explained by changes in pulmonary resistance.

An attempt was made to determine whether pulmonary resistance during oscillatory measurements at the natural frequency ( 5 to $8 \mathrm{cps}$ ) was different from the pulmonary resistance measured at normal breathing rates. In two normal subjects oscilloscopic plots of air flow against esophageal pressure were compared during spontaneous breathing at ordinary respiratory rates and during the application of sinusoidal oscillations to the thorax at its natural frequency. The Mead-Whittenberger subtraction circuit (20) was used to obtain direct oscilloscopic plots of air flow against the resistive component of esophageal pressure. The slopes of the oscilloscopic pressure-flow plots during oscillation at the natural frequency and during slow resting breathing were identical, indicating that the pulmonary component of the total resistance was correctly estimated by the oscillatory method.

Respiratory work. Total respiratory work in kilogram-meters per $1 \mathrm{~L}$ breath (respiratory rate, 20) measured from tank respirator data averaged
0.073 in the normal subjects, 0.095 in the obese normal subjects, and 0.212 in the O.H. patients. The differences between the normal subjects and the two obese groups were significant $(p<0.05$ and 0.001 ). In the three O.H. patients restudied after partial recovery, the total respiratory work averaged 0.147 per $1 \mathrm{~L}$ breath. The mean decrease in total work following clinical improvement was not significant $(p>0.05)$.

In the normal subjects the total work was almost evenly divided between that done upon the lungs and that done upon the thorax. The slight increase in total respiratory work in the obese normal group consisted mostly of work done upon the lung, whereas the increased total work in the O.H. patients involved increases in work done on the thorax (three times the normal average) as well as in that done upon the lungs (twice normal).

Electromyographic observations. The electrical activity of respiratory muscles was investigated for two reasons. The first was to determine whether or not the respiratory muscles were active at end-expiration and other "static" points and to examine the validity of total compliance measurements. The second was to find out whether active expiratory muscle contraction during inspiration could explain differences between the two resistance methods. Observations were made on five of the normal subjects by surface electrode recording of upper intercostal, rectus abdominus, and external oblique potentials during tank respirator measurements. No attempt was made to record diaphragmatic potentials because of its technical difficulty in a conscious subject enclosed in a tank respirator. When respirator cycles did not exceed $30 \mathrm{~cm} \mathrm{H}_{2} \mathrm{O}$ in amplitude and when consistent and reproducible volumepressure loops were being inscribed, respiratory muscle potentials were not detected. During midposition shift measurements of total compliance, electrical silence was present at end-expiration up to pressures of $-50 \mathrm{~cm} \mathrm{H}_{2} \mathrm{O}$.

\section{Discussion}

\section{Static properties}

Validity of measurements. The most important consideration in total compliance measurements in fully conscious voluntarily relaxed subjects is 
whether or not respiratory muscle activity is present. Inspiratory muscle activity would cause overestimation of total compliance; expiratory muscle activity, underestimation. Nims, Conner, and Comroe (26) found total compliance significantly greater in the awake voluntarily relaxed state than in the anesthetized, paralyzed state when the same subjects were studied under both conditions. They considered reflex inspiratory muscle activity as a possible explanation. Although respiratory muscle electrical activity was not detected during our measurements, we cannot exclude inspiratory muscle activity because of the limitations of surface recording and because of our failure to record diaphragmatic potentials. The agreement of results of the two compliance methods (Figure 5), however, makes significant muscle activity unlikely, since it would be improbable that a subject could set his respiratory muscle tone at the same level during the two rather different measurement procedures. The reproducibility of the measurements is apparent and their value in comparing normal with abnormal states established. Whether our measurements represent the true total compliance is not known with certainty.

Further consideration of static properties of the respiratory system demands that gravitational properties be distinguished from true elastic properties. The evidence indicates that obesity may affect both types of static property. Gravitational properties and mass loading have been discussed elsewhere (10).

\section{True elastic properties of the thorax}

The significantly lower total respiratory compliances of the O.H. patients reflect principally their decreased thoracic compliances (averaging only $35 \%$ of normal). The thorax is known to become less compliant at small volumes, and certainly part of the decreased thoracic compliance is due simply to depression of the mid-position so that the obese subject breathes over a less compliant portion of his thoracic volume-pressure curve. Why this depression of the mid-position should be more marked in the patients with the O.H. syndrome than in the obese normal subjects of nearly comparable weight is not known. Naimark and Cherniack's data (9) show de- creased thoracic compliances in all their obese subjects, and the differences in thoracic compliance between their obese hypoventilators and their obese normals are not impressive.

Lung compliances were often low among the obese, especially in the O.H. group whose mean compliance was $42 \%$ below the average normal value. The most tenable explanation for this invokes the observations of Caro, Butler, and Dubois (27) and of McIlroy, Butler, and Finley (28) in which chest strapping decreased lung compliance in normal subjects. Their observations dealt with the acute effects of strapping, and the compliance changes were attributed to closure or collapse of alveolar units. The chronic effects of mass loading should produce similar changes possibly with irreversible collapse of alveoli.

\section{Resistances}

Whereas separate methods gave similar total respiratory compliance values, in the case of the two total resistance methods each gave different results, tank respirator values running two or three times the oscillatory values. Difference in pulmonary or thoracic resistance due to difference in body position is an unlikely explanation because of the small changes in pulmonary and total respiratory resistance (oscillatory method) associated with change from sitting to supine position. Close correspondence between pulmonary resistance as measured during oscillatory measurements and at lower breathing frequencies indicates that the methodologic discrepancy is in the thoracic rather than pulmonary component of total respiratory resistance. Absence of expiratory muscle potentials during tank respirator resistance measurements makes it unlikely that active expiratory muscle opposition is producing spuriously high inspiratory resistances, although this possibility is not absolutely excluded because of limitations of surface recording and incomplete sampling of respiratory muscle activity.

A twentyfold difference in volume displacement per measurement cycle $(1 \mathrm{~L}$ and $50 \mathrm{ml}$, respectively, for tank respirator and oscillatory methods) implies greater passive stretching of respiratory muscles in the respirator method which might produce higher thoracic resistances. Lastly the 
difference might be related to the difference in frequency at which the measurements were made. Since these studies were completed, Mead (29) has found that thoracic resistance in normal subjects indeed appears to vary with frequency, becoming greater at low frequencies and less at higher frequencies. This may explain most of the discrepancy between results of the two resistance methods and suggests that the tank respirator resistance values may be the more pertinent to the spontaneously breathing subject.

\section{Respiratory work}

The close correspondence between total compliance values by the cycling versus the mid-position shift method (Figure 5) suggests that the cycling method correctly determines total respiratory compliance and therefore also the elastic component of total respiratory work. Although a similar internal corroboration of total resistance methods is lacking, the tank respirator method probably gives a reasonably close estimate of the respective component of total respiratory work (see above). Electromyographic silence observed during cycling respiratory work measurements also supports their validity. Absolute validification of work measurements obviously awaits com- parison of measurements made during voluntary relaxation with measurements made after pharmacologic paralysis of the respiratory muscles in the same subjects.

\section{Comparison with data of others}

Table III compares our mean values for the compliance and resistance of the thorax and total respiratory system with published data from five well done studies indicated by the references. Only data obtained on conscious normal and obese males are given. Also included is the normal total inspiratory work value reported by Otis, Fenn, and Rahn (18).

\section{Summary}

1) Total respiratory mechanics were measured in eight normal subjects, ten obese subjects, and four patients with the obesity-hypoventilation (O.H.) syndrome. Total respiratory compliance was significantly decreased in both obese groups, averaging $0.081 \pm 0.007$ in obese normal subjects and $0.045 \pm 0.003$ in the O.H. patients as compared to $0.104 \pm 0.005 \mathrm{~L}$ per $\mathrm{cm}$ $\mathrm{H}_{2} \mathrm{O}$ in the normal subjects. The decreased total compliance in the O.H. group was due principally to lowered thoracic compliance.

TABLE III

Comparison of thoracic and total respiratory compliance, resistance, and work data from the literature

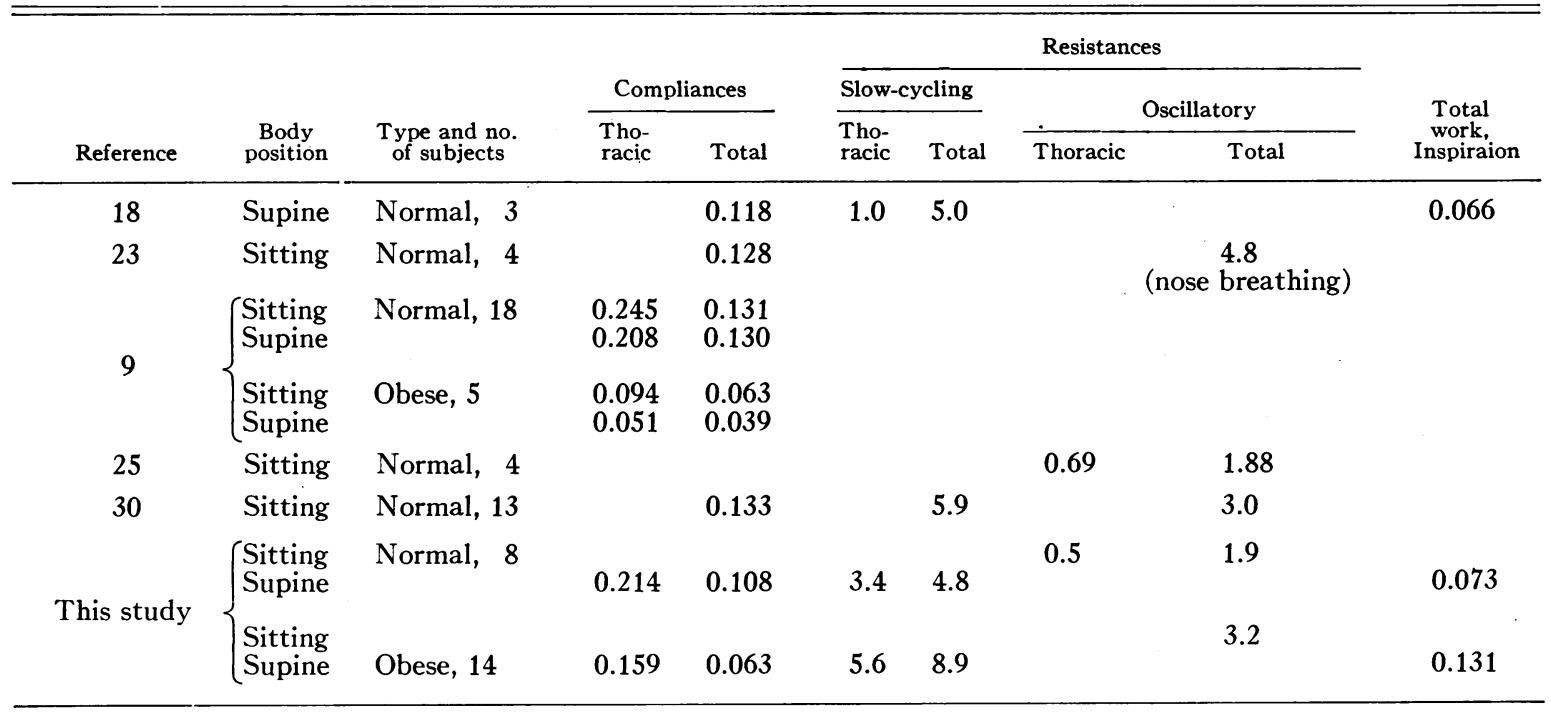

* Only adult normal or obese males studied in the conscious state were considered. Compliances are in liters per centimeter $\mathrm{H}_{2} \mathrm{O}$, resistances in centimeters $\mathrm{H}_{2} \mathrm{O}$ per liter per second, and work in kilogram-meters per 1-L breath at approximately 20 breaths per minute. 
2) Results of two methods of measuring total respiratory compliance were highly correlated ( $r$ $=+0.93$ ).

3) Although total respiratory resistance is somewhat increased in the obese, the amount of increase is not clear. Two independent methods for measuring total respiratory resistance gave disparate results. Differences in the frequencies at which the measurements are made are probably responsible for this methodologic discrepancy, although the effects of respiratory muscle activity have not been entirely excluded.

4) Obese normal subjects had total respiratory work values up to twice normal and averaging 1.3 times normal. Four patients with the O.H. syndrome had values from 2.2 to 3.4 times the average normal value, averaging 2.9 times normal.

\section{Acknowledgments}

The authors gratefully acknowledge the assistance given by Dr. Vladimir Liberson in making electromyographic observations and the technical assistance given by $\mathrm{Mr}$. Frank King, Mr. Andrew Miskowsky, and Mr. Samuel Cooper. We are also indebted to Dr. Robert M. Poske, of West Side V.A. Hospital, Chicago, Dr. Robert W. Carton, of Illinois Research and Educational Hospitals, Dr. Raul M. Casas, of St. Francis Hospital, Evanston, Ill., and Dr. Gordon L. Snider, of Mt. Sinai Hospital, Chicago, who referred obese patients to us and in some instances supplied clinical and physiological data on them as well. Lastly, we are grateful to Dr. Jere Mead, whose criticisms, suggestions, and review of the manuscript were invaluable.

\section{References}

1. Sieker, H. O., E. H. Estes, Jr., G. A. Kelser, and H. D. McIntosh. A cardiopulmonary syndrome associated with extreme obesity (abstract). J. clin. Invest. 1955, 34, 916.

2. Auchincloss, J. H., Jr., E. Cook, and A. D. Renzetti. Clinical and physiological aspects of a case of obesity, polycythemia and alveolar hypoventilation. J. clin. Invest. 1955, 34, 1537.

3. Burwell, C. S., E. D. Robin, R. D. Whaley, and A. G. Bickelmann. Extreme obesity associated with alveolar hypoventilation-a Pickwickian syndrome. Amer. J. Med. 1956, 21, 811.

4. Carroll, D. A peculiar type of cardiopulmonary failure associated with obesity. Amer. J. Med. 1956, 21, 819.

5. Kaufman, B. J., M. H. Ferguson, and R. M. Cherniack. Hypoventilation in obesity. J. clin. Invest. 1959, 38, 500.

6. Fritts, H. W., Jr., J. Filler, A. P. Fishman, and A. Cournand. The efficiency of ventilation during voluntary hyperpnea: studies in normal subjects and in dyspneic patients with either chronic pulmonary emphysema or obesity. J. clin. Invest. 1959, 38, 1339.

7. Bosman, A. R., and H. I. Goldman. The oxygen cost and work of breathing in normal and obese subjects. S. Afr. J. Lab. clin. Med. 1961, 7, 62.

8. Hackney, J. D., M. G. Crane, C. C. Collier, S. Rokaw, and D. E. Griggs. Syndrome of extreme obesity and hypoventilation: studies of etiology. Ann. intern Med. 1959, 51, 541.

9. Naimark, A., and R. M. Cherniack. Compliance of the respiratory system and its components in health and obesity. J. appl. Physiol. 1960, 15, 377.

10. Sharp, J. T., J. P. Henry, S. K. Sweany, W. R. Meadows, and R. J. Pietras. The effects of massloading the respiratory system in man. Submitted for publication.

11. Sharp, J. T., J. P. Henry, S. K. Sweany, W. R. Meadows, and R. J. Pietras. Total respiratory inertance and its gas and tissue components in normal and obese men. Submitted for publication.

12. Kory, R. C., R. Callahan, H. G. Boren, and J. C. Syner. The Veterans Administration-Army cooperative study of pulmonary function. I. Clinical spirometry in normal men. Amer. J. Med. 1961, 30, 243.

13. Darling, R. C., A. Cournand, and D. W. Richards, Jr. Studies on intrapulmonary mixture of gases. III. An open circuit method for measuring residual air. J. clin. Invest. 1940, 19, 609.

14. Ogilvie, C. M., R. E. Forster, W. S. Blakemore, and J. W. Morton. A standardized breath holding technique for the clinical measurement of the diffusing capacity of the lung for carbon monoxide. J. clin. Invest. 1957, 36, 1.

15. Hickam, J. B., and R. Frayser. Spectrophotometric determination of blood oxygen. J. biol. Chem. 1949, 180, 457.

16. Astrup, P. A simple electrometric technique for the determination of the carbon dioxide tension in blood and plasma, total content of carbon dioxide in plasma, and the bicarbonate content in "separated" plasma at a fixed carbon dioxide tension (40 mm. Hg.). Scand. J. clin. Lab. Invest. 1956, $8,33$.

17. Singer, R. B., and A. B. Hastings. An improved clinical method for the estimation of disturbances of the acid-base balance of human blood. Medicine (Baltimore) 1948, 27, 223.

18. Otis, A. B., W. O. Fenn, and H. Rahn. Mechanics of breathing in man. J. appl. Physiol. 1950, 2, 592.

19. Von Neergaard, J., and K. Wirz. Die Messung der Strömungswederstände in den Atemwegen des Menschen, insbesenders bei Asthma und Emphysem. Z. klin. Med. 1927, 105, 51. 
20. Mead, J., and J. L. Whittenberger. Physical properties of human lungs measured during spontaneous respiration. J. appl. Physiol. 1953, 5, 779.

21. Sharp, J. T. The effect of body position change on lung compliance in normal subjects and in patients with congestive heart failure. J. clin. Invest. 1959, 38, 659.

22. Heaf, P. D. J., and F. J. Prime. Compliance of thorax in normal human subjects. Clin. Sci. 1956, $15,319$.

23. Mead, J. Control of respiratory frequency. J. appl. Physiol. 1960, 15, 325.

24. Dubois, A. B., A. W. Brody, D. H. Lewis, and B. F. Burgess. Oscillation mechanics of lungs and chest in men. J. appl. Physiol. 1956, 8, 587.

25. Ferris, B. G., J. Mead, and L. H. Opie. Partitioning of respiratory flow resistance in man. In preparation.
26. Nims, R. G., E. H. Conner, and J. H. Comroe, Jr. The compliance of the human thorax in anesthetized patients. J. clin. Invest. 1955, 34, 744.

27. Caro, C. G., J. Butler, and A. B. Dubois. Some effects of restriction of chest cage expansion on pulmonary function in man: an experimental study. J. clin. Invest. 1960, 39, 573:

28. McIlroy, M. B., J. Butler, and T. Finley. The effect of chest strapping on pulmonary function in normal subjects. Fed. Proc. 1959, 18, 102.

29. Mead, J. Personal communication.

30. Brody, A. W., P. S. O'Halloran, H. J. Wander, J. J. Connolly, Jr., E. E. Roley, and E. Kobold. Ventilatory mechanics and strength: long-term reexaminations and position change J. appl. Physiol. 1960, 15, 561 . 